\title{
Inheritance of Folk Music Culture and School Music Education
}

\author{
Zheng Wei \\ Baicheng Normal University, Baicheng, 137000, China \\ email: 2394724760@qq.com
}

Keywords: Folk Music Culture, Cultural inheritance, School Music Education, Research and Analysis

\begin{abstract}
Folk music is formed in the long-term national development with national characteristics of music. The folk music culture is an important part of the excellent culture of our country. The national music culture contains rich historical connotations and can reflect the historical and spiritual connotations of the national development. Through the excellent teaching of folk music in school education, the students can be infected and nurtured, and the thoughts of students can be more actively and healthily developed. This paper analyzes the relationship between the inheritance of folk music culture and school music education, expounds the importance of the inheritance of folk music culture in music education and the present situation of school music education, and puts forward relevant measures and suggestions for the inheritance of folk music culture.
\end{abstract}

\section{Introduction}

The inheritance and development of folk music culture with the help of school education is the most important form. As an important place of educational inheritance, schools shoulder the important mission of inheriting national music culture, which has important performance significance to the development of folk and cultural heritage. Based on this, the author first analyzes the relationship between the inheritance of folk music culture and school music education, and studies the importance of folk music culture inheritance in music education and the present situation of school music education, puts forward the related strategy suggestion to the folk music culture inheritance, and hopes to have the important function to the folk music culture inheritance.

\section{The Relationship between the Inheritance of Folk Music Culture and School Music Education}

Folk music plays an important role in enriching Chinese culture, which is a form of culture with national characteristics formed in the course of long-term historical development [1]. Folk music culture includes various forms of national life and national development. The national development and the national people create various national cultures in the labor creation, which embodies the development of the national history and the various aspects of the national cultural life, which is not only the display of the national culture and the national language, as well as the aesthetic appreciation of the nation itself. At the same time, it is also a reflection of the diversity of national culture, reflected in national music, the national thought and national soul strength is an important carrier and manifestation of national spirit.

As an important place of educational heritage, schools have important expression significance to the development of national and cultural heritage. The most important form is the inheritance and development of folk music culture with the help of school education. School education shoulders the important mission of inheriting national music and culture. In the process of development in recent years, the school makes great efforts to reform and innovate, continuously explore and practice, carry out the research of folk music culture in place, and ensure that the school own characteristic culture can be effectively carried forward. Cultural construction and propaganda in school education can effectively ensure that the development of national music culture has a solid foundation, and at the same time, in the process of carrying out democratic traditional culture 
education, students and the general public can feel a sense of national pride. On this basis, the inheritance and development of folk music culture can often achieve more efficient results, so the inheritance of folk music culture is closely related to the learning and development of music teaching [2].

\section{The Importance of the Inheritance of Folk Music Culture in Music Education}

With the continuous development of social economy, music is also affected by various aspects. Many kinds of music culture threaten the traditional culture of national music, which results in the development of traditional culture of national music being affected. Therefore, it is necessary to make clear the importance of folk music to the cultivation of the national spirit of the next generation, to ensure that the development and promotion of folk music culture continues, and to persist in carrying forward the folk music culture. It is of great significance to the education of the whole folk music culture and to the cultivation of interest of students in the folk music culture, and it is also helpful to create a new folk music culture that keeps pace with the times [3].

The folk music culture is an important part of the excellent culture of our country, which contains rich historical connotations and can reflect the historical and spiritual connotations of the national development. Folk music forms the music with national characteristics in the long-term national development, so in school education, students are influenced and nurtured mentally by this excellent folk music, so that they can effectively guide the thinking of students to develop more actively and healthily, and can be more aware of the history and culture of the nation and the course of its development while feeling the folk music. In school education, we should actively select and apply excellent folk music works into the teaching work of music class [4]. In actual teaching, teachers should show students photos or videos of the local customs of various ethnic minorities, let students feel different audio-visual effects, provide a more visual teaching content for the whole music classroom teaching, thus help students to understand the connotation and difference of folk culture to promote the inheritance and development of national music with this form.

In the process of school education, the importance of music classroom teaching is often neglected, which leads to the failure to attach importance to the aesthetic education and moral education teaching and guidance of students in music classroom teaching, which results in the enthusiasm of students for music classroom learning being difficult to improve, that has a certain influence on students' understanding and mastery of folk music. In school education, it is necessary to integrate teaching resources and folk music in accordance with the requirements of the new curriculum reform, and to effectively expand relevant teaching resources on the basis of accomplishing the tasks of music teaching objectives. By actively introducing different minority music resources and guiding students to explore national music, we can show students Daur, Mongolian, Oroqun, Uygur, Korean and other ethnic music and broaden their musical horizons. Making students experience different styles of national music, can effectively improve the students' perception of national music, on the basis of actively learning the music culture of the motherland, letting students feel the charm of folk music and improving students' ability to understand and appreciate folk music can effectively improve the aesthetic value of students and make students realize the aesthetic feeling brought about by folk music culture.

\section{The Present Situation of Music Education in Schools}

School education plays an important role in improving the learning ability and comprehensive quality of students, which is of great significance to develop music education in schools to improve music literacy and cultural literacy of students. Music teaching is different from other forms of education, which pays more attention to the guidance of the spiritual aesthetic sense and emotion of students, and can improve the comprehensive quality of students from the perceptual aspect, and often has a variety of educational forms and educational effects. School education has made certain provisions on music education. Music education can effectively improve students' learning ability and interest in learning, and can train students to form healthy interpersonal skills, and effectively 
improve the communication between themselves and students. Generally speaking, music teaching plays an important role in cultivating the comprehensive quality of students, but there are some problems in music education under the current situation [5].

\subsection{Focusing on Skill Training}

In the process of music teaching, many schools neglect the cultivation of musical literacy of students, and often pay attention to the cultivation of students' actual performance ability of music, and do not attach importance to the teaching guidance of students' musical literacy and musical cognition. This type of education may affect the subsequent music learning of students. Music learning in colleges and universities pays more attention to the investigation and requirements of students musical literacy of students. If only the ability of music performance is trained, it will inevitably lead to the difficulty of music learning in colleges and universities.

\subsection{Single Form of School Music Teaching}

Under the current situation, most teachers still follow the traditional teaching methods in the process of teaching folk music, which leads to the boring teaching atmosphere in the music classroom, and teachers often pay attention to the musical performance ability of students. In the teaching evaluation method, it is often used to evaluate the effect of song performance for teachers, ignoring the cultivation of musical literacy of students, resulting that interest of students in learning and learning enthusiasm is difficult to improve [6].

\subsection{Lack of Excellent Works with the Times}

Under the current situation, various forms of musical works in various countries have emerged in endlessly and become more popular. The characteristics of pop music are often more easily accepted by the general public and young students. Therefore, most students prefer the form and characteristics of pop music, coupled with the lack of understanding and learning of national music, resulting in that the interest of students in the study of folk music is difficult to improve, and the perception and appreciation of national music of students is affected.

\section{Measures Taken to Carry Forward the Folk Music and Inherit the Folk Music Culture}

\subsection{Taking the Approach of "Please Coming in" and "Going out"}

"Please coming in", that is, in the teaching of folk music, we should specifically invite professional folk music performers to come to the school classroom and act as folk music teachers and instructors in the school, and let students feel the real form of national music culture. At the same time, students can also be organized to visit actual folk music performances, so that students can learn more deeply about folk music, which can not only enrich musical views of teachers, but also enable students to have a more diversified understanding of the forms of folk music. In the teaching of folk music, professional ethnic historians can be invited to convey to students the history of the development of national culture and the evolution of related cultures, which plays an important role in the students' understanding of national history and culture and the improvement of their own historical and cultural literacy. But "going out" means that in the actual teaching, the school organizes the practice activities, participates in the related style activities, and carries on the thorough and systematic study, lets the student and the teacher all feel the music culture and the national history culture [7].

\subsection{Using Multiculturalism to Develop Folk Music Education}

In order to carry out the education of national music culture, we should pay attention to the propaganda and education of the aesthetic value and the cultural heritage value of music, while the traditional music education neglects the educational guidance of the connotation of music culture and the humanistic spirit, and pay more attention to the mastery of music knowledge and skill. However, the teaching of folk music should pay attention to transmitting the connotation of music culture to the students, so that the students can master and understand the relevant knowledge of 
folk culture, so as to better carry out the education of national music. In the teaching of folk music, teachers can assign homework to students before class, so that students can look up relevant national music materials, deepen their understanding of national culture, and learn more about national life to arouse the interest of students in learning, and then to show students the customs and customs of the nation in the actual teaching process, so as to deepen the undefined understanding of the national culture of students, and to better improve undefined interest of students in learning. In the course of teaching, we should combine the learning effect and learning ability of students, innovate and change the teaching method, renew the teaching idea, improve the interest of students in learning, and let the students feel the joy of music learning in music learning. The application of more diversified teaching ideas, so that students more respect and understanding of national music culture. Teachers use more diversified teaching ideas to make students more respect and understand the folk music culture.

\subsection{Carrying out Various Kinds of Activities of Folk Music Exchange}

Folk music culture contains national customs, folk customs and folk music, so folk music is an important manifestation of national history and culture, and folk music culture is also an important carrier of national emotion and national spirit. In the process of school education, we should insist on respecting tradition and inheriting the classical educational idea, actively carry forward the traditional culture of the nation, we can arrange the form of class meeting to convey the connotation of national music culture to the students, to guide the students to explore and communicate the national music culture, so as to better understand and learn the national music culture [8]. At the same time, the school can organize the activities of national music and culture experience, go deep into the places where the ethnic minorities live together, experience the folk characteristic dance and folk music on the ground, and effectively deepen the understanding of the traditional culture, national music and dance of students. Of course, teachers can guide students to learn minority dance and music through the Internet and the media, and conduct group study and discussion, compile and display the corresponding folk music and dance, that will ensure that students have a deeper and more concrete understanding of folk music and dance, and can also integrate the national spirit and culture embodied in national culture into the learning and growing up process of students to strengthen their national awareness and patriotism and better promote the overall development of students.

\section{Conclusion}

Generally speaking, the inheritance and development of folk music culture through school education is the most important form. As an important place for education inheritance, schools shoulder the important mission of inheriting folk music culture and is of great significance to the development of national and cultural heritage. On the basis of grasping the relationship between the inheritance of national music culture and the school music education, the importance of the inheritance of national music culture in music education is clarified. In view of the current school music education based on the skills training and the single form of music teaching and lack of excellent works with the times, in order to improve the effect and quality of the inheritance of folk music culture, we should actively adopt the method of "please coming in" and "going out", and carry out the education of folk music and the activities of various forms of communication and inquiry of folk music by using multiculturalism, continuously to improve the folk music and cultural heritage of the effect and quality.

\section{References}

[1] ZHANG Meiying, YU Ping. Research on the role of multicultural music education in the inheritance of folk music culture [J]. Education for Chinese After-school (Theory), 2018(31):8+10.

[2] LAI Lijia. The role of multicultural music education in the inheritance of folk music culture [J]. Northern Music, 2018, 38 (18):166. 
[3] TANG Yu. Probe into the inheritance of folk music culture under the theory of multicultural music education [J]. Contemporary Education Research and Teaching Practice, 2018(08):242-243.

[4] HAN Yanting, YIN Aiqing. Thoughts on inheriting folk music culture in school music education [J]. Journal of Northeast Normal University (Philosophy and Social Sciences), 2018(04):241-246.

[5] WANG Shanshan. Significance and function of inheriting folk music culture in preschool music education [J]. China National Exhibition, 2018(06):45-46.

[6] ZHANG Min, ZHAO Yangyang. Discussion on the inheritance and protection of folk music culture by pluralistic music education [J]. Guizhou Ethnic Studies, 2018, 39(05):74-77.

[7] DUAN Ru.The inheritance and development of Ningxia local music culture and the music education in Ningxia Universities taking the Northern University for nationalities as an example[J]. Art Science and Technology, 2018, 31(05):25-26.

[8] HUANG Yongqiang. The inheritance of folk music culture and the reform and innovation of music education in colleges and universities [J]. Home Drama, 2018(14):198. 